\title{
Needs-adapted Data Presentation in e-Information Tools
}

Henning Bergenholtz, Centre for Lexicography, Aarhus School of Business, Aarhus, Denmark ( $h b @ a s b . d k$ ) and extraordinary professor, Department of Information Science, University of Pretoria, Pretoria, South Africa

and

Theo J.D. Bothma, Department of Information Science, University of Pretoria, Pretoria, South Africa (tbothma@up.ac.za) and visiting professor, Centre for Lexicography, Aarhus School of Business, Aarhus, Denmark

Abstract: In the current debate about the status of lexicography there are at least three quite different opinions:

(i) Lexicography does not have or need any kind of own theory but can use all relevant linguistic theories.

(ii) Lexicography needs a special theory for the lexicographical praxis, but this discipline is still a part of linguistics.

(iii) Lexicography is a genuine part of information science and can use theories and learn from practice in the information society, but it also needs special theories for lexicography.

It is the third opinion we will maintain in this paper by discussing the information needs in the information society and partly using the function theory of lexicography.

Keywords: LEXICOGRAPHY, FUNCTION THEORY, INFORMATION TOOL, DICTIONARY, FIXED EXPRESSION, INFORMATION OVERLOAD, INFORMATION STRESS, USER NEEDS, COMPLEX USER SITUATION, CONTEXT, COGNITIVE SITUATION, COMMUNICATIVE SITUATION, OPERATIVE SITUATION, INTERPRETATIVE SITUATION, MONOFUNCTIONAL INFORMATION TOOL, POLYFUNCTIONAL INFORMATION TOOL, INTEGRATED INFORMATION TOOL, DATABASE, DATA PRESENTATION

Opsomming: Data-aanbieding aangepas volgens behoefte in e-inligtinghulpmiddels. In die huidige debat oor die status van leksikografie is daar minstens drie wyd uiteenlopende standpunte:

(i) Leksikografie het nie en benodig ook nie enige tipe eie teorie nie, maar kan van alle relevante taalkundige teorieë gebruik maak.

(ii) Leksikografie benodig ' $n$ spesiale teorie vir die leksikografiese praktyk, maar hierdie dissipline is nog steeds deel van taalkunde.

(iii) Leksikografie is 'n ware deel van inligtingkunde en kan die teorieë gebruik en uit die gebruike in die inligtingsamelewing leer, maar dit benodig spesiale teorieë vir leksikografie. 
Ons handhaaf die laaste standpunt in hierdie artikel waarin inligtingbehoeftes in die inligtinggemeenskap bespreek word met gedeeltelike gebruik van die funksieteorie van leksikografie.

Sleutelwoorde: LEKSIKOGRAFIE, FUNKSIETEORIE, INLIGTINGHULPMIDDEL, WOORDEBOEK, VASTE UITDRUKKING, INLIGTINGOORLADING, INLIGTINGSPANNING, GEBRUIKERBEHOEFTES, KOMPLEKSE GEBRUIKERSITUASIE, KONTEKS, KOGNITIEWE SITUASIE, KOMMUNIKATIEWE SITUASIE, OPERATIEWE SITUASIE, INTERPRETATIEWE SITUASIE, MONOFUNKSIONELE INLIGTINGHULPMIDDEL, POLIFUNKSIONELE INLIGTINGHULPMIDDEL, GEİNTEGREERDE INLIGTINGHULPMIDDEL, DATABASIS, DATA-AANBIEDING

\section{Introduction}

In the function theory of lexicography (Bergenholtz 2010; Bergenholtz and Bergenholtz 2007; Bergenholtz and Bergenholtz 2011; Bergenholtz and Gouws 2007; Bergenholtz and Tarp 2002; Bergenholtz and Tarp 2003; Bergenholtz and Tarp 2005; Gouws and Leroyer 2009; Leroyer 2009; Nielsen 2009; Tarp 2007; Tarp 2008a; Tarp 2008b; Tarp 2008c; Tarp 2009a; Tarp 2009b; Tarp 2011; Tono 2010; Verlinde, Leroyer and Binon 2009) the term 'information tool' is used rather broadly to include any information object from encyclopaedias to telephone directories, travel guides and instruction manuals in addition to dictionaries, lexica, glossaries, etc. This extension is based on two issues, namely that all these information objects are consulted in a non-linear fashion when there is a need for specific information and all information objects are organised in a similar way, that is, they are highly structured based on a predefined set of criteria (alphabetically, grouped according to topics, etc.). The terms 'information object' and 'information tool' will be used in this article to emphasise the fact that the principles described here do not apply only to traditional dictionaries, but to this broader range of information objects that include dictionaries as well. Furthermore, the 'e'-designation is added because even though the theoretical principles apply equally to print and digital information objects, the practical implementation is only feasible in the digital or e-environment.

\section{Users and information stress}

The information society is characterised by an information explosion. Many researchers try to estimate the rates at which information doubles (see, for example, Lyman and Varian 2003). Numbers in such research differ widely and it is probably impossible to be accurate in the estimates. What is clear, however, is that the amount of information available increases consistently and there is no possibility that the rate will decrease. This simply means that there is more information available than any user can conceivably need in any given situation and that, when a user searches for information, he/she is 
overwhelmed by the results. This information overload (in terms of what is presented to the user) causes information stress in the user. The terms 'information overload' and 'information stress' are therefore related causally - 'a' causes 'b' and both are flip sides of the same coin. When a system presents too much information to a user (information overload), the user experiences this as information stress.

The following searches, done in October 2010, illustrate the point. Searching for example for the phrase 'information management' on Google results in close to 14 million results. If this search is repeated in a research environment on Google Scholar, nearly 700000 research items are retrieved. Repeating the same search on EbscoHost (EBSCO Publishing 2010) provides more than 104000 results with more than 51000 peer-reviewed articles, of which more than 8500 have appeared since January 2009. ScienceDirect (ScienceDirect 2010) (SciVerse) provides references to more than 22000 articles and 1750 books, which include more than 4000 articles and 300 books that have been published since January 2009.

This implies that both the general user and the researcher are totally overwhelmed by the amount of available information. (It obviously also means that a search for information should be narrowed down by using more search terms combined with Boolean operators. However, this requires a fairly high level of information literacy that the average user does not have.) The information overload provided by search engines and journal platforms/databases results in information stress for the user. The user becomes totally overwhelmed by the amount of information and does not know how to cope with what is available. This may also result in a situation referred to as 'information death' - the user is so overwhelmed by what is presented that he/she simply turns away from the problem and does not try to satisfy the information need.

A recent survey by LexisNexis (October 2010) reports that "information overload is a remarkably widespread and growing problem among professionals around the world, and one that exacts a heavy toll in terms of productivity, performance and employee morale". It "reveals the pervasive nature of the problem in white collar workforces around the world, and the very real impact that information overload is having on worker productivity, their state of mind and quality of their work product", and adds that "[a]pproximately one in two white collar professionals surveyed report feeling demoralized when they can't manage all the information that comes their way at work" (LexisNexis 2010 International, 2010).

Users would therefore prefer to get exactly the information they need to satisfy their information need in a specific situation. In the context of dictionaries, Haas already formulated this in 1962: "The perfect dictionary is one in which you can find the thing you are looking for preferably in the very first place you look" (Haas 1962: 48). In this quotation, 'dictionary' can equally well be replaced by 'information source'. Any user consulting any information 
source would prefer that it provides him/her with exactly the information he/she needs in the given situation - not more and not less. Bergenholtz and Gouws (2010:3) formulated this as follows: "For the user the type of information source is not important. Important is that he/she retrieves the exact required information as quickly as possible."

The information that the user retrieves should therefore be relevant to his/her information need in the context of the information need, whether this is in "[s]ocial, systemic domain and work task contexts" (Ingwersen 2007), both individual and collective (see Ingwersen 2001; Ingwersen 2007; Ingwersen and Järvelin 2004; Ingwersen and Järvelin 2005). In addition, the information should be correct and complete (i.e. detailed enough) to solve the user's information need, and it should also be understandable to the user (see Bergenholtz and Bergenholtz 2007; Bergenholtz and Gouws 2007).

Search engines such as Google try to increase the relevance of search results (inter alia) based on the country of origin of the user and the countryspecific version of Google. For example, searching for 'information technology' on Google renders around 65 million hits. However, the first pages of results of country-specific versions of Google list different results. This is evident when comparing the results for this search to a sample of other Google versions, such as the American (.com), South Africa (.co.za), Dutch (.nl), Danish (.dk), Spanish (.es), French (.fr) and German (.de) versions. In each case there are a few generic first listings (e.g. to Wikipedia), but thereafter the results differ quite widely, especially in terms of the origin and language of the retrieved sites. Google therefore assumes that a user from South Africa would find results from websites in South Africa on average more relevant than websites from, say, Denmark or Spain (except for a number of very commonly used sites).

Websites sometimes list retrieved items according to how relevant the retrieved items are to the search query. For example, in a digital library such as the ACM Digital Library (2010) and in commercial systems such as Amazon.com (2010) retrieved items can be displayed using different criteria such as relevance, even though the rationale for this relevance ranking is not apparent to the user. In all preceding examples the principle remains the same: from among the full set of records in the database the system tries to display first those items that it perceives as most relevant to the user and then all items are displayed in a descending order of relevance. The reason for this is obvious: the user should not be overloaded with less relevant or irrelevant information, precisely to avoid the stress that information overload causes.

In all the above cases relevance is simply system relevance, i.e. a match between the search query input by the user and the data items in the database. Further dimensions of relevance, such as the possible relevance of the retrieved item to the user's situation (situational relevance), state of knowledge (cognitive relevance), etc. (Cosijn and Ingwersen 2000; Cosijn 2006; Järvelin and Ingwersen 2010) are not taken into account. 
System relevance does not take into account the unique characteristics of the user in any given situation simply because the system has no knowledge about the user. The system does not know what the user's level of knowledge of the topic is - expert, semi-expert or lay person. The system does not know what the user's general and technical language proficiency in the language of the document is - mother tongue speaker or specific level of proficiency in L2/L3. The system does not know what level of detail the user needs - an in-depth discussion or a brief overview. The system does not know for what type of task the user needs the information - a work task, leisure, study, etc. In each of the preceding cases the variables can be plotted on a continuum and be combined in multiple ways. For example, based on only three variables - subject knowledge, general language proficiency and technical language proficiency - Bergenholtz and Bergenholtz (2007) and Bergenholtz and Gouws (2007) identified 30 different types of user. They did not consider the other variables of a user's profile and context that were mentioned above.

The characteristics and context of the user are therefore complex factors that are not taken into account when the system executes a query and presents the results of a search. The information that is offered to a specific user is not optimally relevant to him/her in a specific context and may result in information overload by the system and information stress on the user.

In the preceding section examples were provided from e-resources in general. A similar situation obviously prevails in respect of current e-dictionaries and other e-information tools.

\section{Different information needs over time}

As suggested above, the characteristics of information differ. The characteristics of the user may also differ in various contexts and user needs differ over time in a specific context. Each of these aspects will be discussed briefly.

- Information could be characterised based on detail, e.g. from very little detail to comprehensive detail. (This correlates to a certain extent with the length of the information element - from a single sentence or paragraph to a comprehensive essay/article to a book.) The complexity of the information can differ: an article on the human genome project in a popular news magazine differs widely in complexity from a technical research article on the same topic, but may be less complex than an article prescribed for students at undergraduate level. A specific unit of information could therefore be aimed at a lay person, a semiexpert or an expert. Many permutations of this phenomenon are possible. A short definition can be a very easy definition aimed at the lay person while a highly complex definition could be considered easy by the expert. Similarly, a long essay can be written 'in simple English' for 
the lay person or could contain highly complex scientific terminology and argumentation aimed at the expert.

- Three typical user categories, based on their domain knowledge, were mentioned in the preceding paragraph - a lay person, a semi-expert (or an 'interested'/knowledgeable lay person) and an expert. However, no expert is an expert in all fields. An expert in nuclear physics is most probably not an expert in biomedical research as well, but may be a semi-expert in another field either related to his/her research or in a field that he/she practises as a hobby. One person, therefore, has different characteristics depending on the situation and the context, and this has an impact on the characteristics of the information he/she may need to solve an information-related problem.

- A user's information needs may differ within a specific context. In completing for example a work task (a single context), an individual user (for example an expert) may have a number of different information needs that may differ vastly in terms of the characteristics of the information that he/she requires.

This could be illustrated by means of the following example. In the process of doing research the researcher will typically need only detailed information aimed at the expert. However, in this process, he/she may want to read somewhat more widely than the narrowly defined research problem within a field where he/she is not an expert, especially if the research undertaken is of an inter- and multidisciplinary nature. At this stage the expert may need fairly comprehensive information aimed only at the semi-expert. He/she may, if the situation requires it, move to more complex and detailed information aimed only at the expert. In these readings the expert may come across technical terms for which he/she needs only brief explanations or definitions, again aimed at the semi-expert (or even a lay person). The expert may also read articles (either aimed at the expert or the semi-expert) in a language other than his mother tongue. In this case he/she may need help with text reception, a simple communicative information need, to help him/her to understand the text in L2. The complexity of this reception problem may also differ. In an uninflected language it may be very simple to find a translation equivalent from L2 to L1; however, in a highly inflected language it may be more problematic to identify the root (infinitive/lemma) of a verb to enable the user to find the required translation equivalent.

The above example is represented diagrammatically in Figure 1 below, and is further explained in the bulleted points following the diagram. Attributes of an element are given below the element, indented and placed in square brackets. 


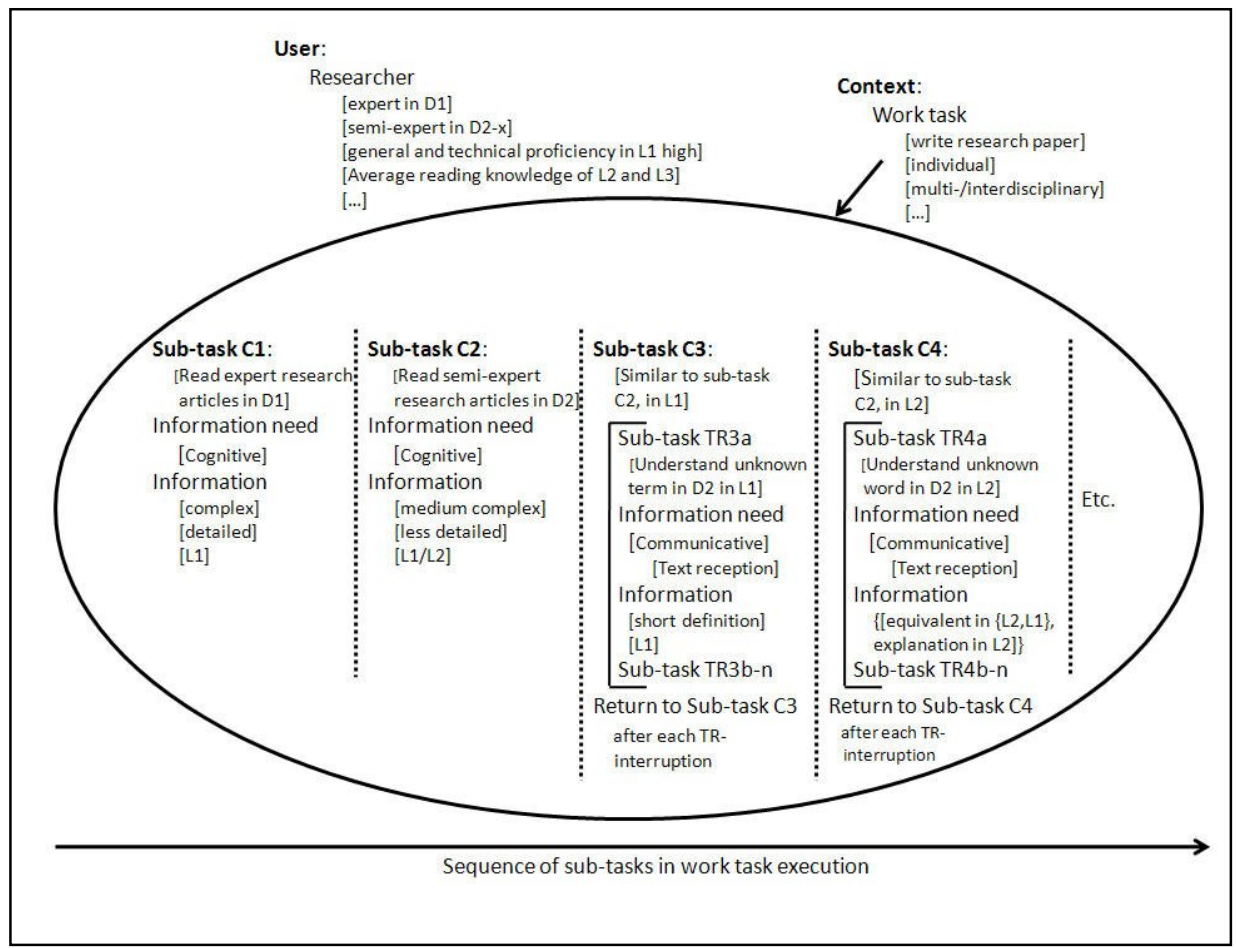

Figure 1: Attributes of user, context, information needs and information during work task execution

Explanatory notes to Figure 1:

- Both the user (a researcher) and the context (a work task) have certain attributes that are given in square brackets. Only some attributes of either are explicated, indicated by [...].

- The arrow at the bottom indicates that the sub-tasks are performed sequentially. However, they are separate and individual, as emphasised by the dotted lines.

- Sub-tasks C1 and C2 ( $\mathrm{C}=$ cognitive) are straightforward. The researcher reads articles to increase his/her knowledge of his/her primary research domain and, in the inter-/multidisciplinary research, also in research domain 2, D2, as well.

- Sub-tasks C3 and C4 are similar to C2, albeit with interruptions.

- While reading an article in sub-task C3, the researcher is interrupted in this cognitive process because of a text reception problem, namely not understanding a technical term in D2, indicated as Sub-task TR3a (TR = text reception; the "a" indicates that this is the first of such interruptions; TR3b-n indicates that such interruptions may reoccur any number of times). $\mathrm{He} / \mathrm{she}$ therefore first has to solve this information need 
before returning to sub-task $\mathrm{C} 3$, typically by referring to a brief definition of the term. Since the document he/she is reading is in L1, the information required to solve the need is also in L1. After solving the information need satisfactorily, the researcher carries on with sub-task C3 itself.

- A similar problem occurs in executing sub-task C4. While reading an article in sub-task $\mathrm{C} 4$, the researcher is interrupted in this cognitive process because of a text reception problem, namely not understanding a word in L2, indicated as Sub-task TR4a and possible further occurrences, indicated by TR4b-n. He/she therefore first has to solve this information need before returning to sub-task C4. Since the document he/she is reading is in L2, the information required to solve the need requires an equivalent in either L2 (a synonym) or L1 (simply the 'meaning' from a bilingual dictionary) or an explanation in L2 (an 'understandable' explanation in a monolingual dictionary). After solving the information need satisfactorily, the researcher carries on with subtask C4 itself.

- The diagram does not make provision for any extra-work task information needs or activities not related to the work task itself, for example external interruptions, etc.

Each of the variables discussed above can be plotted on a continuum, i.e. in terms of complexity there are multiple possibilities, not only three as mentioned above. The same applies to the other variables.

If all these variables and the continuum on which they can be plotted are combined in a single diagram, the result is an n-dimensional complex matrix of elements. This is further complicated if the standard requirements for information (i.e. being accurate, up-to-date, reliable and relevant) and the requirement that e-information should be available on the user's platform of choice, from desktop to mobile, are also taken into account. This complexity is represented diagrammatically in Figure 2, where only two characteristics of information are considered without the further variables or the fact that all of these elements can be plotted on a continuum.

It is therefore "clear that it is extremely complex to satisfy a specific information need of a specific user in a specific situation, taking into account all the possible permutations of the characteristics of users and information" (Bothma 2011). Bergenholtz and Gouws (2007: 584) come to the conclusion that a reference work is of high quality if it contains what the user requires - and only what the user requires - to satisfy his/her information needs. Such products are not feasible in a paper-based environment and are currently only to a very limited extent available in the e-environment. By means of modern information technologies it is, however, becoming feasible to address these issues. 


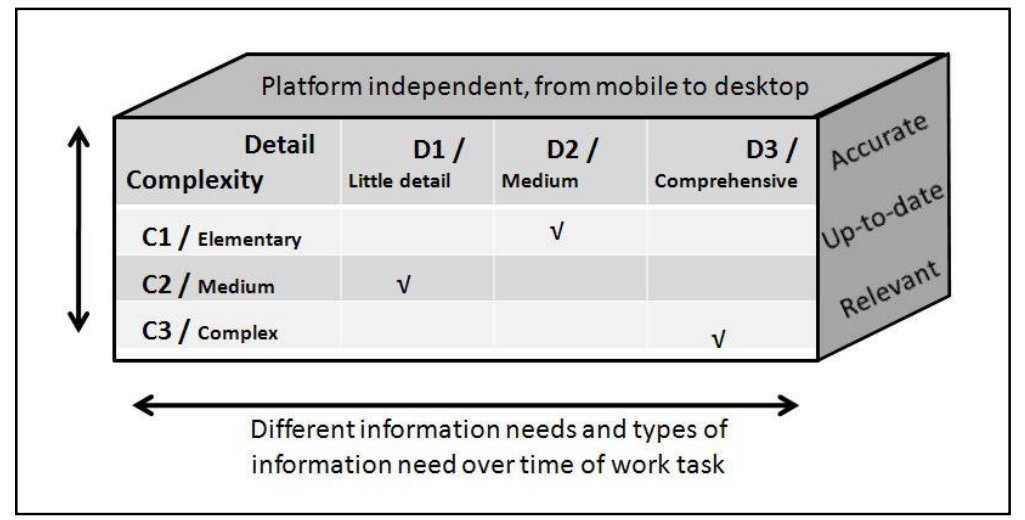

Figure 2: Matrix of possible characteristics of information (Bothma 2011)

\section{Dictionaries as information tools}

If someone does not know something, he/she is in what we call an 'extrainformation tool' situation. This person could decide not to find out what he/she does not know. Alternatively, he/she could ask someone for help, look in a manual, a user guide, a handbook, a telephone directory or a dictionary or undertake a Google search or any other kind of information search in printed or electronic information tools. If he/she uses a dictionary (or a lexicon or an encyclopaedia or whatever name the lexicographical tool might have), the potential dictionary user is in an 'extra-lexicographical' situation. Looking in one or more dictionaries is a 'dictionary use' situation. In some cases the use of a dictionary would be the best choice but in many others certainly not. We therefore prefer to speak about 'extra-information tool' situations. We can distinguish between four basic situations:

- Cognitive situations

- Communicative situations

- Interpretative situations

- Operative situations

In cognitive situations the potential user has a need for knowledge of some kind. The purpose is not to use it in the concrete situation, e.g. during text reception or in a specific situation to act or react in that situation, but simply to get the knowledge. The user wants to know or to have the sought-after knowledge and stores it in the brain for later use. The most commonly used informa- 
tion tools in cognitive situations are dictionaries, handbooks, databases and different search engines used for searching the Internet.

In communicative situations the potential user has a problem with or doubts about the process of written or oral communication and needs some help or recommendation for the text problem. The most commonly used information tools in communicative situations are dictionaries and different search engines used for searching the Internet.

In operative situations the potential user has a need for assistance in connection with physical or mental operations. There is a need for guidelines for what and how the user has to act to carry out a certain instruction. The most commonly used information tools in operative situations are user guides, manuals, road maps and search engines.

In interpretative situations the potential user has a need for assistance to interpret a non-language sign of some kind, e.g. a traffic sign. The right interpretation is normally needed to be able to act in the correct way. The most commonly used information tools in interpretative situations are information material from authorities and different organisations.

To understand the above classification of user situations it is important to make a clear distinction between an operative situation where someone simply intends to do something (act in a certain way) and a cognitive situation where someone selects knowledge that can be used later in another situation where a decision must be made to act in the most relevant way. Likewise, it is not the same to be in a communicative situation and a cognitive situation. In the former, the user has a text problem and, for example, does not understand a part of a text, cannot translate it or needs help to be able to go on with the production of the text. In the latter, the user selects knowledge that can be used later in connection with a text problem. The crucial point in this theory is that it is the situation that leads to the need for an information tool, and it is the nature of the help that is required that is essential for the description of the situation. The fact that information obtained by a user to fulfil his/her needs in a specific situation can also be used in another situation, is not relevant for the current concrete situation. It is at best a side effect (not a part of the situation) and not a demand for data presentation in the information tool currently used. In the same way it is not a relevant description of a specific user need if the user in another, perhaps similar situation, has learned something new or that the facts have changed. This is simply a new situation where the user would perhaps need another information tool. A tool is a tool. This means that a tool has a function according to the basic competence of the potential information tool user and his/her needs.

The function we know most about is the communicative function, or more precisely, the different communicative functions categorised as text reception, text production, translating and text correction (Bergenholtz and Tarp 2002; Bergenholtz and Tarp 2003; Tarp 2008b). These four main functions have to be divided according to different user competencies in different situations: 
1. What is the users' native language?

2. At what level do users master their native language?

3. At what level do users master a foreign language?

4. How extensive is the users' experience of translating between the languages in question?

5. What is the level of the users' general cultural and encyclopaedic knowledge?

Other characteristics may be relevant for a particular dictionary, but the above are the most important for profiling a specific user group. Determining user characteristics is the first step that lexicographers should take to establish user needs, which are not abstract phenomena but related to concrete situations. Lexicographers should therefore identify these situations, distinguish them from one another and analyse them before establishing what the need of a specific type of user may be in a particular situation. The theory of lexicographic functions distinguishes between four main groups of situations of use. Communicative situations involve existing or planned written or oral communicative acts between two or more persons. In these instances, lexicographers intervene indirectly through their dictionaries when the interlocutors encounter some kind of communication problem that they attempt to solve by consulting a dictionary. Dictionaries that satisfy such needs are called communicative dictionaries.

For the kind of communicative dictionaries that are compiled to assist in the text reception process, one should first distinguish between general language and specialised language dictionaries. For the latter, one should distinguish between at least three levels of specialist: lay persons, semi-experts and experts. Some specialised language specialists however, distinguish between up to ten different kinds of specialist (Kalverkämper 1990). For each type one could describe a certain function and in the best-case scenario offer a special dictionary. This tool should also take into account whether the user has the explanation language as mother tongue or not. For translational tools one could differentiate much more with an indefinite number of functions and, thus, an indefinite number of needed monofunctional dictionaries. Such a solution is of course not practical. Well-known solutions with highly polyfunctional dictionaries can in our opinion not help the user accurately and quickly enough. In fact, in many cases they provide an information overload that leads to information stress or even information death, because the user gives up on finding what is needed from among the immense amount of available data. Instead of an offer that includes all kinds of bonus information, the meaning item in the communicative situation 'reception' is enough; all further detailed information is superfluous and disturbing. The real choice is whether a dictionary maker decides to provide only one monofunctional dictionary for all user types (e.g. 
providing explanations in the mother tongue and intended for all users, including specialists, semi-experts and lay persons) or whether it is possible to compile different reception dictionaries for different user types. Although in both cases we refer to monofunctional dictionaries, it is clear that these are different levels of monofunctional dictionaries.

The following example shows results for three monofunctional dictionaries for fixed expressions taken from a single database (the three dictionaries are MEANING OF FIXED EXPRESSIONS, USE OF FIXED EXPRESSIONS and KNOWLEDGE ABOUT FIXED EXPRESSIONS). The intended user type has Danish as mother tongue. If someone reads a text and has a reception problem with some kind of fixed expression (idiom, proverb, phrase verb, quotation, etc.) the user can search in a reception dictionary with a search string for the whole fixed expression or for a part of it. A potential user reads a text with the expression klæde sig $i$ sæk og aske (to dress in sackcloth and ashes) and is not sure what the expression means. He/she can use $i$ sæk og aske as a search string and, by pressing the button 'understand an expression', find the entry below in the dictionary MEANING OF FIXED EXPRESSIONS. He/she gets only the meaning of the expression, nothing else:

\section{Betydning \\ udtryk for at vise ydre tegn på sorg \\ eller anger}
Meaning
Expression for certain external signs of sorrow or regret

If the user knows the expression or has obtained it by a search as shown above, he/she may be in doubt as to how the expression can be used. He/she enters the search string klæde $i$ sæk og aske (to put on sackcloth and ashes), presses the button 'Write a text' and finds the following entry in the dictionary USE OF FIXED EXPRESSIONS (this time, unlike in other entries, without collocation entries):

\begin{tabular}{|l|l|}
\hline $\begin{array}{l}\text { Faste vendinger } \\
\text { iføre sig sæk og aske } \\
\text { klæde sig i sæk og aske }\end{array}$ & $\begin{array}{l}\text { Fixed expression } \\
\text { to put on sackcloth and ashes } \\
\text { to wear sackcloth and ashes } \\
\text { to lie in sackcloth and ashes } \\
\text { omvende sig i sæk og aske } \\
\text { sidde i sæk og aske } \\
\text { være iført sæk og aske }\end{array}$ \\
\hline $\begin{array}{l}\text { Betydning } \\
\text { to sit in sackcloth and ashes } \\
\text { to be dressed in sackcloth and ashes } \\
\text { eller anger at vise ydre tegn på sorg }\end{array}$ & $\begin{array}{l}\text { Meaning } \\
\text { Expression for certain external signs } \\
\text { of sorrow or regret }\end{array}$ \\
\hline $\begin{array}{l}\text { Grammatik } \\
\text { nogen klæder sig i sæk og aske }\end{array}$ & $\begin{array}{l}\text { Grammar } \\
\text { Someone wears sackcloth and ashes }\end{array}$ \\
\hline $\begin{array}{l}\text { Eksempler } \\
\text { Askeonsdag er den første af fastens }\end{array}$ & $\begin{array}{l}\text { Quotations } \\
\text { Ash Wednesday is the first of the } 40\end{array}$ \\
\hline
\end{tabular}


40 dage. I middelalderen mødte de bodfærdige denne dag i kirke iført sæk og aske.

Sammen med aflad skulle det syndige menneske også sone sin straf ved at få besked af præsten på at bede et vist antal Ave Maria - og evt. gå i sæk og aske og leve af vand og brød i en aftalt periode. days of Lent. In the Middle Ages penitents went to church dressed in sackcloth and ashes on this day. Besides getting a letter of indulgence, the priest could also order the sinner to do penance by saying a number of Ave Marias - and if necessary to go dressed in sackcloth and ashes and to take nothing but water and bread for a set period.

The above entry gives the grammatical information that the subject should be a person, as well as two examples that can be used for an own text.

However, the user may possibly want further information, for example, about the history behind the expression. He/she can then type in the same search string and press the button 'know more about a fixed expression'. In the dictionary KNOWLEDGE ABOUT FIXED EXPRESSIONS he/she then finds partly the same data as in the text production dictionary; additional data is, however, also provided about the type, style and history behind the expression:

\begin{tabular}{|c|c|}
\hline $\begin{array}{l}\text { type / stil } \\
\text { idiom } \\
\text { neutral } \\
\end{array}$ & $\begin{array}{c}\text { Expression type and style } \\
\text { idiom } \\
\text { neutral style } \\
\end{array}$ \\
\hline $\begin{array}{l}\text { Anmærkninger } \\
\text { Udtrykket bruges både i Det Gamle } \\
\text { og Det Nye Testamente, hvor } \\
\text { personerne giver udtryk for stor sorg } \\
\text { eller beklagelse, fx i Esters Bog 4.1: } \\
\text { "Da Mordokaj fik at vide, hvad der } \\
\text { var sket, flængede han sine klæder; } \\
\text { han klædte sig i sæk og aske, gik } \\
\text { rundt i byen og skreg højt og bittert". } \\
\text { Man tager simple klæder på og strør } \\
\text { aske på hovedet: "De fastede den dag } \\
\text { og klædte sig i sæk og strøede aske } \\
\text { på deres hoved og flængede deres } \\
\text { klæder" (Første Makkabæerbog 3.47). }\end{array}$ & $\begin{array}{l}\text { Note } \\
\text { The expression occurs in the Old and } \\
\text { the New Testaments when people } \\
\text { express great sorrow or pity, e.g. in } \\
\text { Esther 4.1: "When Mordecai per- } \\
\text { ceived all that was done, Mordecai } \\
\text { rent his clothes, and put on sackcloth } \\
\text { and ashes, and went out into the } \\
\text { midst of the city, and cried with a } \\
\text { loud and a bitter cry". One wears } \\
\text { simple clothes and scatter ashes on } \\
\text { one's head: "They fasted that day and } \\
\text { put on sackcloth and sprinkled ashes } \\
\text { on their heads and tore their clothes" } \\
\text { (1 Maccabees 3.47). }\end{array}$ \\
\hline
\end{tabular}

The examples we have shown are from a quite specialised dictionary. The principles illustrated in these examples can be applied in exactly the same way in all other kinds of information tools, not only in (specialised) dictionaries. 


\section{Integrated information tools}

From the preceding theoretical and practical examples it is clear that it is optimal and feasible to present the user with exactly the required information needed to solve an information-related problem. Care should therefore be taken to ensure that the user is not overwhelmed by an overload of information and that his/her information need is solved in a specific situation with exactly the required information.

The dictionary examples focused on the communication process, took into account both text reception and text production information needs, and also provided an example of a cognitive need. Information needs in communicative situations are best understood, especially in terms of how these relate to the use of dictionaries. This is evident from many of the publications of the Centre for Lexicography at the University of Aarhus (Centlex) and others within the framework of the function theory of lexicography. Finer or more detailed calibrations of cognitive situations and the nature of the information tools required to satisfy cognitive information needs within the framework of the function theory have not been researched in any detail. The following two sections will focus on the nature of information tools that can be used in any of the four situations. They will take the characteristics of information and users as discussed in section 2 as departure point.

To recap briefly:

- Information has specific characteristics that relate to complexity, detail and language.

- Users, from lay persons to experts, can be placed on a continuum.

- Users need exactly the information that solves their information need - not more and not less.

From the examples in section 4 it is clear that it is feasible to structure data in a dictionary environment and to provide (monofunctional) tools in such a way that these ideals can be met. Is this also feasible in the broader range of einformation tools as defined in section 1 ?

The rest of section 5 will focus on the nature of such integrated information tools, while section 6 will discuss how the data are to be organised and presented to provide these tools.

In the dictionary examples in section 4 the three dictionaries use one database. This implies that the lexicographer selected what data are necessary in any given situation to solve the user's information need and provided individualised tools for this purpose. For example, in the text reception case, all data not related to text reception are not presented to the user and the user is provided with a very limited view of the information in the database. Put differently: a filter has been applied to the database to ensure that only informa- 
tion related to the specific search string and the specific information need is displayed. In other words, a user need with the characteristics [search string, text reception] is matched with data with the characteristics [text reception]. The same applies to a text production situation: a user need with the characteristics [search string, text production] is matched with data with the characteristics [text production]. Language attributes could also be added, for example to indicate that the language of the data to be displayed should be L1 or L2.

The task of the lexicographer or information specialist is to design tools that enable this matching process to take place.

In a communicative situation, finer granularity of information needs has been identified, namely text reception and text production. In the case of a cognitive situation no such finer granularity has yet been discussed and no such tools have been developed to date. For example, in the Centlex dictionaries as published by Ordbogen.com (Ordbogen.com 2010), there is simply a single button for cognitive functions, implying (to a certain extent) that the characteristics of information required in all cognitive situations are identical. In all cases, selecting a cognitive search option provides the user with everything that is in the database. However, our arguments in section 2 have made it clear that information has different characteristics, inter alia complexity and detail, in addition to language (in relation to the user's mother tongue, designated as L1/L2, etc.).

If the communicative function is subdivided, it is logical that the cognitive function should also be subdivided. (The same goes for the operative and interpretative functions, neither of which will be discussed in this article.) This process of subdivision and further refining of (sub) functions is also the task of the lexicographer and information specialist.

The technologies by means of which a user can access the information have already been hinted at. The first two include searching (and browsing) and filtering. A third technology, adaptive hypermedia, has to be added. Each of these will be discussed briefly.

Primary access to any information in a database occurs by means of searching and browsing and a combination of the two. This is discussed in more detail in Bothma (2011). Searching implies that the user enters a search string in a search box (with the required intellectual input to construct a search string), whereas browsing implies that the user navigates predefined links by simply clicking on the links. Currently, all e-information tools support searching and browsing. Many have an 'advanced search' option, but often this search option in e-dictionaries is not optimal and many of the functions of advanced search are not available (e.g. those found in e-journal platforms such as EbscoHost (EBSCO Publishing 2010) and ScienceDirect (ScienceDirect 2010)).

By executing a search in a standard search engine, all data that match the search string entered by the user are returned. In the Centlex dictionaries, however, the data are filtered - only data related to the specified function are returned. This means that the metadata of a data element are taken into account 
to decide whether they should be displayed or not. In the Centlex dictionaries there is no explicit metadata, but metadata are implicit in terms of the fields in which the data occur. For example, when a text reception search is executed, data from a specific predefined set of fields are displayed; when a text production search is executed, data from a different predefined set of fields are displayed (even though there may be overlaps). This implies that the lexicographer or information specialist has decided that certain fields in a certain order are relevant for a text production information need and not for a text reception information need, and vice versa.

No such granularity, however, exists when a cognitive search is executed. If information required to satisfy a cognitive information need is placed in specific fields in a database, it would be possible to present the user with the information for the specific cognitive need only. If complexity and detail (the characteristics given in section 2) are used, it would result in information elements with nine characteristics, examples of which are given below:

Data element 1 [little detail, elementary]

Data element 2 [little detail, complex]

Data element 3 [comprehensive, elementary]

Data element 4 [comprehensive, complex]

Etc.

The same subdivisions can be made for any data element the lexicographer or information specialist includes in the database, for example historical comments, grammatical detail, etymology, multimedia, etc.

By providing a filtering mechanism it would be possible to provide the user in a cognitive situation with exactly the information he/she needs. However, at a practical level this may require too many predefined tools to be created - in the preceding example it would require nine tools. A more effective method to accomplish such granularity would involve providing the user with the tools to define the tool himself/herself by selecting specific check boxes that then display only the data that conform to the filter, as in the following:

\begin{tabular}{|rl|rc|}
\hline Detail (select one) & & \multicolumn{2}{|c|}{ Complexity (select one) } \\
\hline Little & $\bigcirc$ & Elementary & $\bigcirc$ \\
\hline Medium & $\bigcirc$ & Medium & $\bigcirc$ \\
\hline Comprehensive & $\bigcirc$ & Complex & $\bigcirc$ \\
\hline
\end{tabular}

The user could then, by clicking two selections, specify one of nine possible combinations according to which the data would be filtered.

Filtering in this case would be on a per-case basis, i.e. each time the user uses the tool, he/she has to set the filter. It is also possible to set the filter as 
part of a user profile and/or automated tracking of user behaviour, as explained in Bothma (2011).

Data are filtered in response to user needs and the content displayed for the user is adapted accordingly. The principles of adaptive hypermedia, as explained in Bothma (2011), are therefore applied.

Since user needs are not constant it is essential that the user remains in control of the information presented to him/her and he/she should be able to change the parameters of the search or profile or the nature of the adapted content at any stage.

In designing such an e-information tool, the lexicographer or information specialist can decide on a number of 'common' views of the database in line with the function theory, and provide additionally the possibility of a number of customised views. This would then enable the lexicographer and information specialist to conceive e-information tools "capable of meeting all the users' needs in specific types of situations" (Tarp 2009a: 292) by providing "dynamic articles [...] structured in different ways according to each type of search criteria", "articles that are especially adapted", allowing users to "define their own profile", resulting in "the 'individualization' of the lexical product, adapting to the concrete needs of a concrete user" (Tarp 2009b: 57, 59, 61). In the preceding quotation 'lexical product' can easily be replaced by 'e-information tool' to indicate that the principles apply much more widely than simply to dictionaries.

The principles discussed in relation to the subdivision of cognitive information needs can be expanded to include operative and interpretative information needs, and even further subdivisions of communicative information needs. Such subdivisions will not be attempted in this article.

The product of such development will be a set of information tools that can provide exactly the right information to a user in a given situation. Such a set of tools will be supported by one database; each tool will be a separate view of the database, either predefined by the lexicographer or information specialist or customised in terms of specific selections by the user. Each tool will be monofunctional, since the view that it provides on the data involves a single function at the level of granularity required by the user.

\section{Data presentation}

To provide such a customisable set of information tools requires a specific design of the database or set of databases. The database could physically be one database with a number of relational tables or a number of individual databases linked logically. For the user this distinction is irrelevant. However, at the programming level this distinction is important and requires very careful planning. The database could be a relational database with multiple tables and fields, or it could be an XML database. In a relational database the different attributes of the individual data elements will be reflected in the different fields that are used. In an XML database the attributes of individual data elements will be defined through metadata in an RDF schema (both concepts are briefly 
discussed in Bothma (2011)). The underlying principles, however, remain the same.

One example of a physical single database or logical database (set of databases) will suffice. In the current dictionaries of Centlex published by Ordbogen.com (Ordbogen.com 2010), each of the 'main dictionaries' (Ordbogen over faste vendinger, Musikordbogen and Regnskabsordbøgerne) is supported by its own database, i.e. three physical databases. It is possible to search each of these databases individually, but it is also possible to do a search simultaneously over all of them (i.e. the three dictionaries mentioned as well as other dictionaries, depending on the user's subscription). For the sake of simplicity, reference will be made only to the afore-mentioned three dictionaries. In the second case the databases are the equivalent of a single logical database (even though they are not physically one database). It would be possible to integrate the three separate databases into one physical database, even though this will be a non-trivial and extremely complex venture.

From the user's side, however, there is no difference. When he/she logs into the site, he/she has the option to search 'all dictionaries' with a single search string (i.e. all databases) or to immediately filter the search by selecting a domain-specific dictionary. If the user decides on a domain-specific dictionary, he/she then has the option to filter the search further by deciding whether the data are required for (for example) text reception, text production or a cognitive function (as illustrated in section 4). The user therefore selects a further filter to provide a customised view of the database. These filters imply that the data are uniquely identifiable as relevant to a text reception, text production or cognitive need.

The structure of the database reflects the access methodologies envisaged by the lexicographer or information specialist. The levels of granularity that can be selected by the user must be matched by the attributes of the individual data elements in the database. This can be illustrated by the following example:

For a text production dictionary, the lexicographer or information specialist needs to decide what data elements are important for the user in a text production environment. These could include (but are not limited to) the meaning of an element, grammatical attributes, collocations and examples. Each of these will then be placed in a separate field or individually marked up with metadata in an RDF schema. Since this granularity is already reflected in the database, it is a trivial task to provide the user with a filter in the text production dictionary to see only meaning, grammatical elements, collocations or examples. However, it could be possible to provide even finer granularity, for example at the grammatical level, to put gender, form of plural, etc., in separate database fields (or to mark them up separately as metadata). A user could, in such a case, select to see only the gender of a noun when this is the only information that is needed in a text production task. This is currently partially possible in the Base lexicale du français (2010). The same principle applies to the other sub- 
fields for text production, as well as to the cognitive, operative and interpretative information needs.

If the data for all these sub-functions are put into different database fields or are properly marked up by means of metadata, it is trivial to provide filters to show only these data. Interface design could, however, be more problematical. The screen could become quite cluttered and users may get confused about how to navigate between and select options. A possible solution would be to provide popup windows or dropdown menus. In both cases, the user could be given the choices between searching and getting more options, as in Figure 3 below.

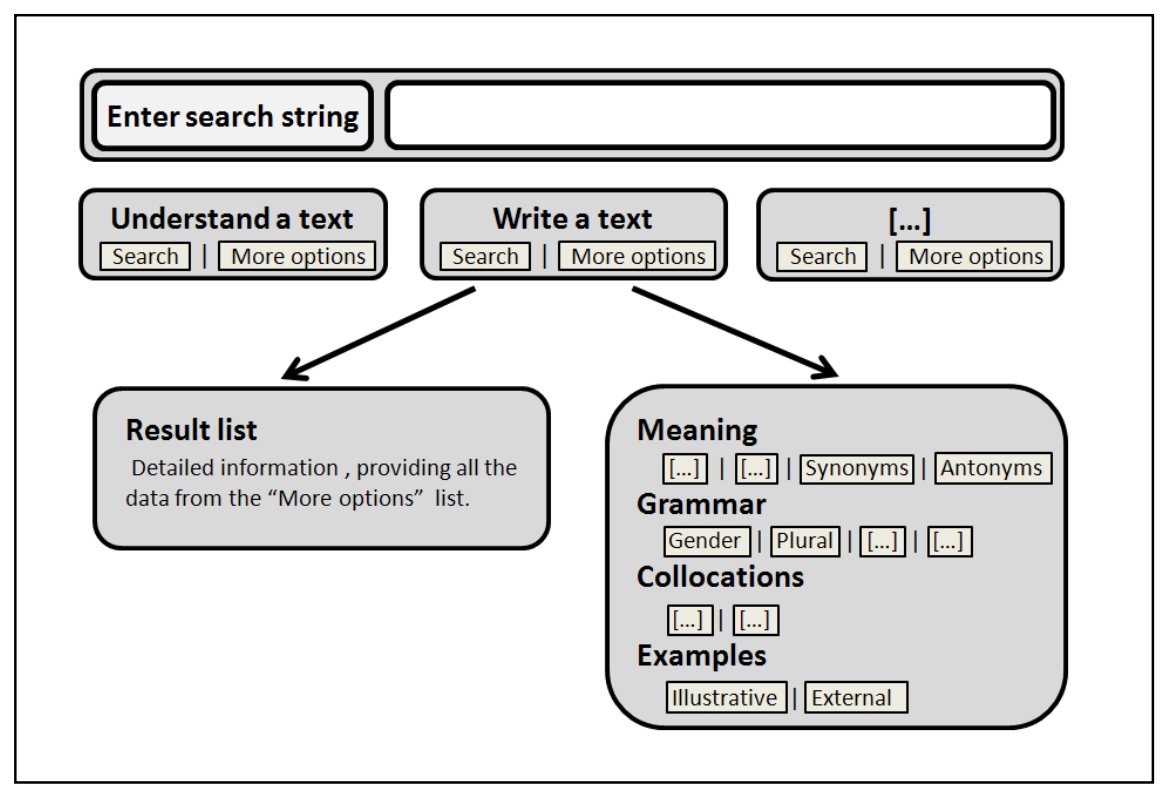

Figure 3: Popup or dropdown menus for customisation

In a text production environment, therefore, the user enters a search string, and then clicks on 'Search' to see all information regarding text production. He/she can also click on 'More options' and then select to see, for example, only 'Gender'. Designing detailed submenus for other functions is fairly trivial, but depends on the granularity that the lexicographer or information specialist adopted for the data.

Hence, by using a relational database structure with a high level of granularity or by marking up data in an XML database with detailed metadata it is possible to provide a highly customised view of the database. Such a view will satisfy the specific information need of the user in a given situation. 
When in a specific work task situation a user knows that he/she will need (for example) only collocations, he/she could set this criterion as part of his/her profile at the beginning of a consultation session, thereby obviating the need to go through the selection process in each query. As indicated earlier, it remains essential that the user be able to reset this profile at any stage in his/her work.

The database structures discussed thus far imply that the lexicographic or information specialist team create all data in the database themselves. Currently it is very common in reference works to refer to secondary resources as well as to general web resources, as is generally the case in Wikipedia (2010) by means of links selected by the domain specialist. This principle can easily be incorporated in the structures outlined in this section, either in separate data fields or as part of any data field within which such a reference would be relevant. It is, however, not necessary for the authoring team to select all such cross-referenced data (such as a single encyclopaedia entry or YouTube video) themselves. Links can be provided to selected large open access data sets as well, as discussed in Bothma (2011). Such links are selected only when the user requires additional information to satisfy his/her information need in a specific situation (typically in a cognitive situation). Both these options may well lead to information overload, but it is the user's choice to decide whether to click on such external links or not.

The user therefore customises the information that he/she accesses in any given information need situation and remains in control of exactly how much or how little information is made available to him/her by the set of e-information tools.

\section{Requirements for e-information tools}

A good tool is one that is able to fulfil the needs of a certain user group by giving quick access to the data and by providing relevant and correct data in a way understandable to this user group. It does not send the user into information death by burdening him/her with a vast amount of unneeded data.

Such a tool must necessarily be a monofunctional tool prepared for a certain user group with a certain type of information need and in a certain type of user situation. However, most printed and electronic lexicographic information tools are not monofunctional, but highly polyfunctional. They are intended for a very broad user group with very different user needs and for quite different usage situations. One therefore often sees as a main thesis in many metalexicographical papers that the more data and the more different data types are provided (even though the user may not be looking for these data) the better the dictionary is (Varantola 2002: 31) - a direct contradiction of the principles of the function theory and what is proposed in this paper. 
Lexicographers and information specialists have the possibility to prepare certain tools in such a way that the information type presented corresponds to the general knowledge about needs, e.g. one only needs definitions (semantic items) in a monofunctional tool for a certain user group with a need for help in receptions problems. Having created only one database we can offer different monofunctional tools, e.g. the following from a database with 14 fields, searching in four of them for a monofunctional text production dictionary:

\begin{tabular}{|c|l|c|}
\hline $\begin{array}{c}\text { Fields searched }+ \\
\text { order of search }\end{array}$ & \multicolumn{1}{|c|}{ Field } & $\begin{array}{c}\text { Order in } \\
\text { dictionary entry }\end{array}$ \\
\hline 1 & 1. Core field & 2 \\
\hline & 2. Meaning & 3 \\
\hline & 3. Further meaning item & 4 \\
\hline & 4. Grammar & \\
\hline & 5. Remark(s) & 1 \\
\hline & 6. Internet link & \\
\hline & 7. Fixed expression(s) & 5 \\
\hline & 8. Style & 6 \\
\hline & 9. Classification of the fixed \\
& expression & 7 \\
\hline 4 & 10. Collocation(s) & 8 \\
\hline & 11. Example(s) & \\
\hline & 12. Synonym(s) & \\
\hline & 13. Antonym & \\
\hline & 14. Association(s) & \\
\hline
\end{tabular}

Depending on their specific information needs in a given situation, some users may prefer another search order, searches in more fields, the data presented in another order or presented from different/additional fields. In the end there would be the possibility of an unlimited number of different dictionaries based on the customisation principles discussed above and the number of fields in the database. The question of the number of users making use of such advanced searches and presentations is not really an important point of argumentation. Whether it is $2 \%$ or $20 \%$ of the users does not matter. It would simply be an unnecessary technical possibility if they were not to be used by any user at all.

However, the different conceptions with the described technical possibilities are really important if we are dealing with information tools with relevant, correct and up-to-date data. A good tool must be completed within a few years. If not, the content is not up to date when the dictionary is published. In Molecular Biology, for example, we have seen that the amount of knowledge doubles within 18 months. It may be argued that development is not so rapid in all fields. In the Accounting dictionary project, however, that Aarhus Uni- 
versity is undertaking in cooperation with colleagues from Valladolid, there are so many national and international changes in terminology and in the official rules for using the terms that a 3- or 4-year old dictionary will in many cases be misleading. A dictionary is of course never finished in the sense that one can stop working on it to refine and update the data. If one were to stop updating the data, the dictionary would become obsolete and not be usable except as a documentation tool of an earlier period. In some cases (depending on the subject area) this would occur after only a few years and in others the dictionary might stay current for perhaps more than 20 years.

An information tool with updated, relevant and correct data is unfortunately seldom produced in the required short time or presented as a really helpful monofunctional tool.

\section{Conclusion}

One of the reasons for the lack of innovation in e-lexicography is that lexicography is usually treated as a part of linguistics and lexicographic tools are primarily compiled by specialists with a linguistic background. Our main thesis, namely that lexicography is not a part of linguistics but a part of information science does not support this line of thought. We need different kinds of experts for different tools. For example, for a music dictionary one needs to involve experts in at least three fields: firstly an expert in lexicography, secondly an expert in lexicographical databases, and thirdly an expert in music theory and history of music. For a general language text production dictionary for L1speakers one also needs an expert in lexicography and an expert in lexicographical databases, but then obviously a linguist. Thus, different kinds of experts are needed for different tools, and this does not necessarily always include a linguist. We do, however, need tools for special problems, not polyfunctional tools. The expert called lexicographer could be called a special kind of information science expert.

Our argument does not imply that the administrative affiliation of all lexicographers at universities must be changed. Some lexicography units could if they deal mostly with lexicography for communicative needs - stay in language departments. But normally and in most cases it would be more natural for lexicography to be treated as a part of information science. In our opinion, the lexicographer could be seated in an interdisciplinary centre that belongs at the same time to the faculty of science, the faculty of social sciences and the faculty of humanities. What we need in the information society (also at universities) is flexibility.

\section{References}

ACM Digital Library. 2010. [Online]. Available: http:/ /portal.acm.org. Accessed October 2010.

Amazon.com. 2010. [Online]. Available: http:/ /www.amazon.com. Accessed October 2010. 
Base lexicale du français. 2010. [Online]. Available: http:/ / ilt.kuleuven.be/blf. Accessed October 2010.

Bergenholtz, H. 2010. Access to and Presentation of Needs-adapted Data in Monofunctional Internet Dictionaries. Presentation at the Acceptance of an Honorary Doctorate at the University of Valladolid, Valladolid, Spain, 17 June 2010.

Bergenholtz, H. and I. Bergenholtz. 2007. Kvaliteten af de leksikografiske definitioner i ordbøger, leksika og encyklopædier. LexicoNordica 14: 11-34.

Bergenholtz, H. and I. Bergenholtz. 2011. A Dictionary is a Tool, a Good Dictionary is a Monofunctional Tool. Fuertes-Olivera, P.A. and H. Bergenholtz (Eds.). 2011. E-Lexicography. London/New York: Continuum.

Bergenholtz, H. and R.H. Gouws. 2007. Korrek, volledig, relevant. Dít is die vraag aan leksikografiese definisies. Tydskrif vir Geesteswetenskappe 47(4): 568-586.

Bergenholtz, H. and R.H. Gouws. 2010. A New Perspective on the Access Process. Hermes, Journal of Language and Communication Studies 44: 1-25.

Bergenholtz, H. and S. Tarp. 2002. Die moderne lexikographische Funktionslehre. Diskussionsbeitrag zu neuen und alten Paradigmen, die Wörterbücher als Gebrauchsgegenstände verstehen. Lexicographica 18: 253-263.

Bergenholtz, H. and S. Tarp. 2003. Two Opposing Theories: On H.E. Wiegand's Recent Discovery of Lexicographic Functions. Hermes, Journal of Linguistics 31: 171-196.

Bergenholtz, H. and S. Tarp. 2005. Verteilungsstrukturen in Wörterbüchern. Barz, I., H. Bergenholtz and J. Korhonen (Eds.). 2005. Schreiben, Verstehen, Übersetzen, Lernen. Zu ein- und zweisprachigen Wörterbüchern mit Deutsch: 119-126. Frankfurt am Main: Peter Lang.

Bothma, T.J.D. 2011. Filtering and Adapting Data and Information in the Online Environment in Response to User Needs. Fuertes-Olivera, P.A. and H. Bergenholtz (Eds.). 2011. E- Lexicography. London/New York: Continuum.

Cosijn, E. and P. Ingwersen. 2000. Dimensions of Relevance. Information Processing and Management: An International Journal 36(4): 533-550.

Cosijn, E. 2006. Relevance Judgements within the Context of Work Tasks. 2006. Proceedings of the 1st International Conference on Information Interaction in Context, IIiX: 20-29. New York: ACM.

EBSCO Publishing. 2010. [Online]. Available: http://www.ebscohost.com. Accessed October 2010.

Gouws, R. and P. Leroyer. 2009. Verhoogde leksikografiese toeganklikheid in die oorgang van ' $n$ toeristewoordeboek na 'n toeristegids as naslaanbron. Tydskrif vir Geesteswetenskappe 49(1): 145-159.

Haas, M.R. 1962. What Belongs in a Bilingual Dictionary? Householder, F.W. and S. Saporta (Eds.). 1962. Problems in Lexicography: 45-50. Bloomington: Indiana University.

Ingwersen, P. 2001. Cognitive Information Retrieval. Annual Review of Information Science and Technology 34: 3-51.

Ingwersen, P. 2007. Context in Information Interaction - Revisited 2006. Bothma, T.J.D. and A. Kaniki (Eds.). 2007. ProLISSA 2006: Proceedings of the Fourth Biennial DISSAnet Conference. Farm Inn, Pretoria, 2-3 November: 13-23. Pretoria: Infuse.

Ingwersen, P. and K. Järvelin. 2004. Context in Information Interaction. Bothma, T. and A. Kaniki (Eds.). 2004. Progress in Library and Information Science in Southern Africa (ProLISSA): Proceedings of the Third Biennial DISSAnet Conference: 301-310. Pretoria: Infuse.

Ingwersen, P. and K. Järvelin. 2005. The Turn: Integration of Information Seeking and Retrieval in Context. Dordrecht: Springer. 
Järvelin, K. and P. Ingwersen. 2010. User-oriented and Cognitive Models of Information Retrieval. Bates, M. (Ed.). 2010. Encyclopedia of Library and Information Sciences: 5521-5534. London: Taylor \& Francis.

Kalverkämper, H. 1990. Der Begriff der "Fachlichkeit« im modernen Italienischen. Lexikalische Systematik und textuelle Integration. Quardini di Semantica. Rivista internazionale di semantica teorica e applicata 11: 79-115.

KNOWLEDGE ABOUT FIXED EXPRESSIONS = Henning Bergenholtz under medvirken af Esben Bjærge. 2010. Betydning af faste vendinger. Database and Design: Richard Almind. Odense: Ordbogen. com. (www.ordbogen.com)

Leroyer, P. 2009. Balancing the Tools: The Functional Transformation of Lexicographic Tools for Tourists. Nielsen, S. and S. Tarp. 2009b. Lexicography in the 21st Century. In Honour of Henning Bergenholtz: 103-122. (Terminology and Lexicography Research and Practice, Volume 12). Amsterdam: John Benjamins.

LexisNexis 2010 International Workplace Productivity Survey. 2010. [Online]. Available: http:/ /www. multivu.com/players/English/46619-LexisNexis-International-Workplace-Productivity-Survey. Accessed October 2010.

Lyman, P. and H.R. Varian. 2003. How Much Information? 2003. [Online]. Available: http://www2. sims.berkeley.edu/research/projects/how-much-info-2003.

MEANING OF FIXED EXPRESSIONS = Henning Bergenholtz under medvirken af Esben Bjærge. 2010. Betydning af faste vendinger. Database and Design: Richard Almind. Odense: Ordbogen.com. (www.ordbogen.com)

Nielsen, S. 2009. Reviewing Printed and Electronic Dictionaries. A Theoretical and Practical Framework. Nielsen, S. and S. Tarp 2009b. Lexicography in the 21st Century. In Honour of Henning Bergenholtz: 23-42. (Terminology and Lexicography Research and Practice, Volume 12). Amsterdam: John Benjamins.

Nielsen, S. and S. Tarp. 2009a. Introduction: Nothing is More Practical Than a Good Theory. Nielsen, S. and S. Tarp. 2009b. Lexicography in the 21st Century. In Honour of Henning Bergenholtz: ix-xi. (Terminology and Lexicography Research and Practice, Volume 12). Amsterdam: John Benjamins.

Ordbogen.com. 2010. [Online]. Available: http://www.ordbogen.com. Accessed October 2010.

ScienceDirect. 2010. [Online]. Available: http://www.sciencedirect.com. Accessed October 2010.

Tarp, S. 2007. Lexicography in the Information Age. Lexikos 17: 170-179.

Tarp, S. 2008a. The Third Leg of Two-legged Lexicography. Hermes, Journal of Language and Communication Studies 40: 117-131.

Tarp, S. 2008b. Lexicography in the Borderland Between Knowledge and Non-knowledge. General Lexicographical Theory with Particular Focus on Learners' Lexicography. (Lexicographica. Series Maior 134). Tübingen: Max Niemeyer.

Tarp, S. 2008c. Revival of a Dusty Old Profession. Hermes, Journal of Language and Communication Studies 41: 175-188.

Tarp, S. 2009a. Reflections on Lexicographical User Research. Lexikos 19: 275-296.

Tarp, S. 2009b. Reflections on Data Access in Lexicographic Works. Nielsen, S. and S. Tarp. 2009b. Lexicography in the 21st Century. In Honour of Henning Bergenholtz: 43-65. (Terminology and Lexicography Research and Practice, Volume 12). Amsterdam: John Benjamins. 
Tarp, S. 2011. Lexicographical and Other e-tools for Consultation Purposes: Towards the Individualization of Needs Satisfaction. Fuertes-Olivera, P.A. and H. Bergenholtz (Eds.). 2011. E- Lexicography. London/New York: Continuum.

Tono, Y. 2010. A Critical Review of Lexicographical Functions. Lexicon 40: 1-26.

USE OF FIXED EXPRESSIONS = Henning Bergenholtz under medvirken af Esben Bjærge. 2010. Brug af faste vendinger. Database and Design: Richard Almind. Odense: Ordbogen.com. (www. ordbogen.com)

Varantola, K. 2002. Use and Usability of Dictionaries: Common Sense and Context Sensibility. Corréad, M.-H. (Ed.). Lexicography and Natural Language Processing. A Festschrift in Honour of B.T.S. Atkins: 30-44. Göteborg: EURALEX.

Verlinde, S., P. Leroyer and J. Binon. 2009. Search and You Will Find. From Stand-alone Lexicographic Tools to User-driven Task and Problem-oriented Multifunctional Leximats. International Journal of Lexicography 23(1): 1-17.

Wikipedia. 2010. [Online]. Available: 2010. http:/ / en.wikipedia.org. Accessed October 2010. 